\section{( OPEN ACCESS}

\title{
Lupuzor/P140 peptide in patients with systemic lupus erythematosus: a randomised, double-blind, placebo-controlled phase IIb clinical trial
}

\author{
Robert Zimmer, ${ }_{1}^{1}$ Hugo R Scherbarth, ${ }^{2}$ Oscar Luis Rillo, ${ }^{3}$ Juan Jesus Gomez-Reino, ${ }^{4}$ \\ Sylviane Muller ${ }^{5}$
}

\begin{abstract}
Handling editor Tore K Kvien
1 ImmuPharma, Mulhouse,

France

${ }^{2}$ Servicio de Reumatología, Hospital Interzonal General de Agudos 'Dr Oscar Alende', Mar del Plata, Argentina

${ }^{3}$ Servicio de Reumatología, Hospital Sirio Libanés, Buenos Aires, Argentina

${ }^{4}$ Rheumatology Unit, Hospital Clinico Universitario, Universidad de Santiago de Compostela, Santiago, Spain ${ }^{5}$ CNRS, Institut de Biologie Moléculaire et Cellulaire, Strasbourg, France
\end{abstract}

\section{Correspondence to}

Dr Robert Zimmer,

ImmuPharma, 5 rue du Rhône Mulhouse 68000, France; robert.zimmer@immupharma. com

This article is dedicated to the memory of Dr Jean-Marie Geiger, medical officer of this trial.

Accepted 23 October 2012 Published Online First 21 November 2012

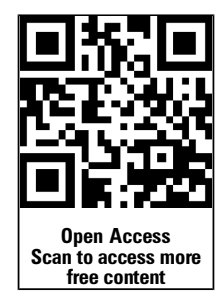

To cite: Zimmer $R$ Scherbarth HR, Rillo OL, et al. Ann Rheum Dis 2013;72:1830-1835.

\section{ABSTRACT}

Objectives To evaluate treatment with the peptidebased agent, Lupuzor, in a double-blind, randomised, placebo-controlled study of patients with systemic lupus erythematosus.

Methods Patients who met $\geq 4$ of the American College of Rheumatology criteria, had a score of $\geq 6$ on the Systemic Lupus Erythematosus Disease Activity Index 2000 (SLEDAI-2K) and did not have an A score on the British Isles Lupus Assessment Group (BILAG)-2004 scale were eligible. 149 intention-to-treat (ITT) patients were randomly assigned to receive Lupuzor $(200 \mu \mathrm{g})$ subcutaneously every 4 weeks ( $n=49$; group 1 ) or every 2 weeks ( $n=51$; group 2$)$ or placebo $(n=49$; group 3$)$ in addition to standard of care (SOC). A target population (136 ITT patients) consisting of patients having a clinical SLEDAI score $\geq 6$ at week 0 was considered. The clinical SLEDAI score is the SLEDAI-2K score obtained by omitting low complement and increased DNA binding components.

Results In the ITT overall population, $53.1 \%$ in group $1(p=0.048), 45.1 \%$ in group $2(p=0.18)$ and $36.2 \%$ in the placebo group achieved an SLE Responder Index (SRI) response at week 12 . In the target population, the results were more impressive: $61.9 \%$ in group 1 $(p=0.016), 48.0 \%$ in group $2(p=0.18)$ and $38.6 \%$ in the placebo group achieved an SRI response at week 12 . An interim analysis including 114 patients from the target population demonstrated an even better efficacy (according to SLEDAI score) in group 1 compared with placebo $(67.6 \%$ vs $41.5 \%(p<0.025)$ at week 12 and $84.2 \%$ vs $45.8 \%(p<0.025)$ at week 24$)$. The most common adverse event was a mild injection-site erythema.

Conclusions Lupuzor/200 $\mu \mathrm{g}$ given three times at 4-week intervals during 12 weeks in addition to SOC is efficacious and generally well tolerated.

Systemic lupus erythematosus (SLE) is a chronic autoimmune syndrome affecting various organs and characterised by increased levels of self-antigen reacting antibodies. ${ }^{1-3}$ SLE has a complex, polygenic inheritance. ${ }^{4} 5$ It is highly polymorphic and its clinical manifestations are sometimes difficult to distinguish from those of other inflammatory diseases. Patients with SLE are generally treated with corticosteroids and other immunosuppressive agents that are efficient in most patients but remain palliative and not curative. ${ }^{6-8}$ Significant morbidity and mortality are often consequences of the cytotoxic therapeutic regimens used to treat harmful nephritis which develops in patients.

Advances in understanding the pathogenesis of the autoimmune diseases have led to the development of peptide-based treatments that aim to reinstate tolerance to self without the need for immunosuppression. $^{7910}$ Theoretically, the administration via a tolerogenic route of peptides that mimic the naturally processed antigen when bound to a major histocompatibility complex (MHC) molecule would induce peptide-specific tolerance, a scheme whereby peripheral autoreactive $\mathrm{T}$ and, possibly, B cells would be deviated or suppressed via various mechanisms, including the involvement of regulatory $\mathrm{T}$ cells.

Lupuzor (formerly P140 peptide, IPP-201101) is a 21-mer linear peptide which comes from the small nuclear ribonucleoprotein $\mathrm{U} 1-70 \mathrm{~K}$ and is phosphorylated at the Ser140 position. ${ }^{11}$ Although the mechanism of action of Lupuzor has not been fully elucidated, studies in the MRL/lpr lupus-prone murine model and using peripheral blood mononuclear cells from patients with SLE have shown that it displays tolerogenic and immunomodulatory effects leading to the inhibition of $\mathrm{T}$ cell reactivity with MHC-presented self-peptides. ${ }^{11-16}$ P140 peptide reduces proteinuria, vasculitis and dermatitis and prevents production of antibodies to double-stranded (ds) DNA in MRL/lpr mice.

In an open-label, dose-escalation study of 20 patients with moderately active SLE, patients who received a low dose of Lupuzor $(200 \mu \mathrm{g}$ at weeks 0 , 2 and 4) showed significant improvement in physician's global assessment (PGA) and SLE Disease Activity Index (SLEDAI) scores, and the drug was generally well tolerated. ${ }^{17}$ Here, we report the results of a randomised, double-blind, placebocontrolled study of Lupuzor in patients with SLE. The results show a clinical and statistical improvement of disease activity in a population of patients with a clinical SLEDAI 2000 (SLEDAI-2K) score $\geq 6$.

\section{PATIENTS AND METHODS}

\section{Patients}

Adult patients aged 18-68 years with an established diagnosis of SLE according to the revised American College of Rheumatology classification criteria, ${ }^{18} 19$ a score of $\geq 6$ on the SLEDAI- $2000^{19}$ and a positive test result for antinuclear antibodies were eligible for the study. Most patients were women (96\%). 
All patients were white and the majority of patients (64\%) were Hispanic. The clinical score included all components of the total score except assessments for antibodies to dsDNA and complement (C3 or C4).

Patients were not eligible for the study if they had received an A score on the revised British Isles Lupus Assessment Group (BILAG)-2004 ${ }^{20} 21$ scale during screening; were able to bear children and did not use a reliable method of contraception; had received intravenous steroids within the 4 weeks before baseline; had received intravenous immunoglobulins, or tacrolimus or ciclosporin A suppressive drugs within the 3 months before baseline; had received cyclophosphamide or a biological agent within the 12 months before study entry; had B cell levels that had not yet normalised after receiving a B-cell-depleting agent; had received or planned to receive a live vaccine within the 3 months before the start of study treatment or within the 3 months after treatment cessation; had a history of malignancy (except basal cell carcinoma or cervical carcinoma in situ $>5$ years before study entry); had clinically significant abnormalities on a chest radiograph or electrocardiogram that were not related to SLE; or had any medical condition unrelated to SLE that might have increased the risk to the patient or interfered with study evaluations (eg, heart failure, infection, liver failure or uncontrolled diabetes mellitus).

If patients were receiving oral corticosteroids, the weekly cumulative dose must not have exceeded the equivalent of $80 \mathrm{mg}$ of prednisone or $72 \mathrm{mg}$ of budesonide and the dose must have been stable during the 4 weeks before study entry. Patients who were receiving antimalarial drugs, methotrexate, leflunomide, mycophenolate mofetil or azathioprine must have started them $\geq 3$ months before study entry and the daily dose must have been stable during the 4 weeks before study entry. Patients who had previously taken corticosteroids, antimalarial drugs, methotrexate, mycophenolate mofetil or azathioprine must have received the last dose $\geq 4$ weeks before study entry. Patients who had previously taken leflunomide must have received the last dose $\geq 8$ weeks before study entry unless they underwent an adequate cholestyramine wash-out. Patients who were taking angiotensin-converting enzyme inhibitors or angiotensinreceptor antagonists must have been receiving stable doses for $\geq 4$ weeks before baseline assessment.

\section{Study design}

This phase IIb, randomised, double-blind, placebo-controlled trial was conducted between February 2008 and July 2009 in four countries-namely, Argentina (12 centres), Bulgaria (one centre), Romania (five centres) and Spain (three centres) - that is, a total of 21 study sites. Eligible patients were randomly assigned in a $1: 1: 1$ ratio to receive subcutaneous injections of Lupuzor $200 \mu \mathrm{g}$ every 4 weeks (group 1), Lupuzor $200 \mu \mathrm{g}$ every 2 weeks (group 2) or placebo (group 3) together with standard of care (SOC). Randomisation was stratified by study site.

Patients, investigators and study personnel were blinded to study treatment group assignment. The active study drug was provided as a lyophilised powder in $2 \mathrm{ml}$ sterile vials containing $200 \mu \mathrm{g}$ of Lupuzor and $54 \mathrm{mg}$ of mannitol as excipient; placebo vials contained $54 \mathrm{mg}$ of mannitol only. The study drug was given every 2 weeks to maintain blinding. Patients in group 1 received injections of Lupuzor $200 \mu \mathrm{g}$ at weeks 0 (baseline), 4 and 8 and injections of placebo at weeks 2, 6 and 10. Patients in group 2 received injections of Lupuzor $200 \mu \mathrm{g}$ at weeks 0 (baseline), 2, 4, 6, 8 and 10. Patients in group 3 received injections of placebo at weeks 0 (baseline), 2, 4, 6, 8 and 10 .
This study was conducted according to good clinical practice and the principles outlined by the International Conference on Harmonisation. Each site's institutional review board or ethics committee reviewed and approved the protocol. All patients provided written informed consent before participating in the study.

\section{Procedures and assessments}

The study consisted of a 2-week screening period, a 12-week treatment period during which the study drug was given and a 12-week follow-up period during which no study drug was given but patients received SOC and were followed up for efficacy and adverse events (AEs). The primary end point was the percentage of patients who achieved a response according to the SLE Responder Index (SRI) at week 12. Patients who showed a reduction from baseline in the SLEDAI- $2 \mathrm{~K}$ score of $\geq 4$ points, no increase in the PGA score of $>0.3$ point on a visual analogue scale of $0-3$, no new A score on the BILAG-2004 and $\leq 1$ new B score were considered to be SRI responders. Secondary end points included changes from baseline in the SLEDAI-2K, BILAG-2004 changes and PGA scores and the percentages of patients with disease flares according to the Safety of Estrogen in Lupus Erythematosus National Assessment (SELENA) Flare Index. ${ }^{22}$ Treatment failures were considered to have occurred in patients who had a severe flare according to the SELENA Flare Index, received an increase in steroid dose to $\geq 80 \mathrm{mg}$ prednisone equivalent each week, received intravenous steroids, received an increased dose or initiation of immunosuppressive therapy, or received biological agents, and these patients were withdrawn from the study.

\section{Statistical analysis}

A sample size of 204 patients (68 patients for each treatment group) was considered to be sufficient to detect a $20 \%$ difference in the proportion of patients achieving a clinical response according to the SRI, assuming that $25 \%$ of patients in the placebo group and $45 \%$ of patients treated with Lupuzor achieved an SRI response. Efficacy analyses were conducted on all randomised patients who received $\geq 1$ dose of the study drug and had at least one efficacy measurement recorded. Patients who discontinued treatment or for whom treatment had failed (see above) were considered to be non-responders in the efficacy analysis. The last observation was carried forward and used in place of missing values for continuous variables in the efficacy analysis. Discrete variables were analysed using a $\chi^{2}$ test. Continuous variables that approximately adhered to a normal distribution according to the D'Agostino k-squared test were determined using an analysis of variance. Continuous variables that were not normally distributed were analysed using a Kruskal-Wallis test. Statistical significance was set at $\alpha=0.050$ (two-sided) for each Lupuzor treatment group versus placebo.

A non-scheduled interim analysis was conducted to determine if the study needed to be stopped for safety and/or efficacy reasons and to inform the clinical development programme. The interim analysis included 114 randomised patients (approximately two-thirds of the initially planned sample size) from the target population who should have completed the treatment period (week 12) at the date of analysis as well as all patients having completed week 24 at the cut-off date. The efficacy measure for the interim analysis was the percentage of patients with a reduction of $\geq 4$ points in the SLEDAI- $2 \mathrm{~K}$ score from baseline to week 12 and week 24. The results of the interim analysis were reviewed by an interim data review committee and the decision was made to stop enrolment of new 
patients and to let the 149 patients already enrolled complete the study.

This study is registered under European Union Drug Regulating Authorities Clinical Trials (EudraCT) number 2007-004892-21.

\section{RESULTS}

\section{Study groups}

Figure 1 shows the trial profile. One hundred and forty-nine patients were randomised as 49 assigned to group 1, 51 to group 2 and 49 to group 3. Table 1 shows the demographic and baseline disease characteristics of participants. Medical history related to SLE was generally comparable across the three groups. Malar rash, photosensitivity, arthritis, immunological disorders and anti-nuclear antibody were the most frequently reported American College of Rheumatology criteria for SLE diagnosis in each group. Baseline characteristics of the groups were generally well balanced, except for the mean level of antibodies to dsDNA, which were lower in group $3(75.2 \mathrm{IU} / \mathrm{ml})$ than either groups 1 (132.9) or 2 (120.0). Concomitant drug use was generally equally balanced between the three groups, except that patients in group 3 were less likely to be receiving corticosteroids and more likely to be receiving antimalarial agents than patients in groups 1 or 2 .

\section{Interim efficacy analysis (weeks 12 and 24)}

Of the 114 target patients in the interim analysis (figure 1), 23/ 34 patients $(67.6 \%)$ patients in group $1(p<0.025), 20 / 39$ patients $(51.3 \%)$ in group $2(\mathrm{p}=0.19)$ and $17 / 41$ patients $(41.5 \%)$ in group 3 (placebo) achieved a SLEDAI response at week 12 (table 2). At week 24, 16/19 (84.2\%) p<0.025 in group 1 and 14/21 patients (66.7\%) in group 2 were responders compared with $45.8 \%$ of patients only in group 3 (placebo).

\section{Final intention-to-treat (ITT) efficacy analysis (weeks 12 and 24)}

Of the 149 patients randomly assigned to treatment, complete safety analysis (see below) data were available for all and efficacy analysis data for 147 patients at week 12 (figure 1). During the 12-week treatment period, a total of $13 / 149$ patients discontinued treatment: $4 / 49$ patients $(8.2 \%)$ in group $1,1 / 51$ patients $(2.0 \%)$ in group 2 and $8 / 49$ patients $(16.3 \%)$ in group 3 .

\section{Efficacy in the ITT overall population}

Twenty-six of 49 patients $(53.1 \%)$ in group $1(p<0.05), 23 / 51$ patients $(45.1 \%)$ in group $2(p=0.18)$ and $17 / 47$ patients (36.2\%) in group 3 achieved an SRI response at week 12 (table 3). Globally the number of responders increased at week 24 in comparison with week 12 despite an absence of treatment and even more under placebo. Twenty-nine of 49 patients $(59.2 \%)$ in group 1, 30/51 in group 2 (58.8\%) and 26/49 (53.1\%) achieved an SRI response at week 24. No statistical difference was seen (table 3).

\section{Efficacy in the ITT target population}

Despite the fact that this population has not been defined at the beginning of the study, the changes in the inclusion criteria led us to carefully analyse this population (clinical SLEDAI score $\geq 6$ ) as this population will be the phase III population. The percentage of patients in group 1 who achieved an SRI response $(26 / 42 ; 61.9 \%)$ during the treatment period was statistically higher than that of the placebo group $(p=0.016)$ (table 4 , figure 2). At week 24, the responder rate in this target group achieved a high score $(29 / 42 ; 69.0 \%)$. The difference between groups did not reach statistical significance.

Of the 24 components of the SLEDAI-2K total score, the following six components contributed significantly to the score at baseline: arthritis, rash, alopecia, mucosal ulcers, increased DNA antibody binding and low complement. Among the components that were positive at baseline, four (arthritis, rash, alopecia and mucosal ulcers) showed changes during the course of the study. Scores of the other components remained essentially unchanged. The apparent clinical benefit observed for patients who received $200 \mu \mathrm{g}$ Lupuzor every 4 weeks compared with those who received placebo every 2 weeks was mainly due to an improvement in articular and cutaneous symptoms (arthritis and rash) at week 12 .

\section{Safety results}

Lupuzor was generally well tolerated. The overall incidence of AEs through week 24 in the 149 patients was similar among the

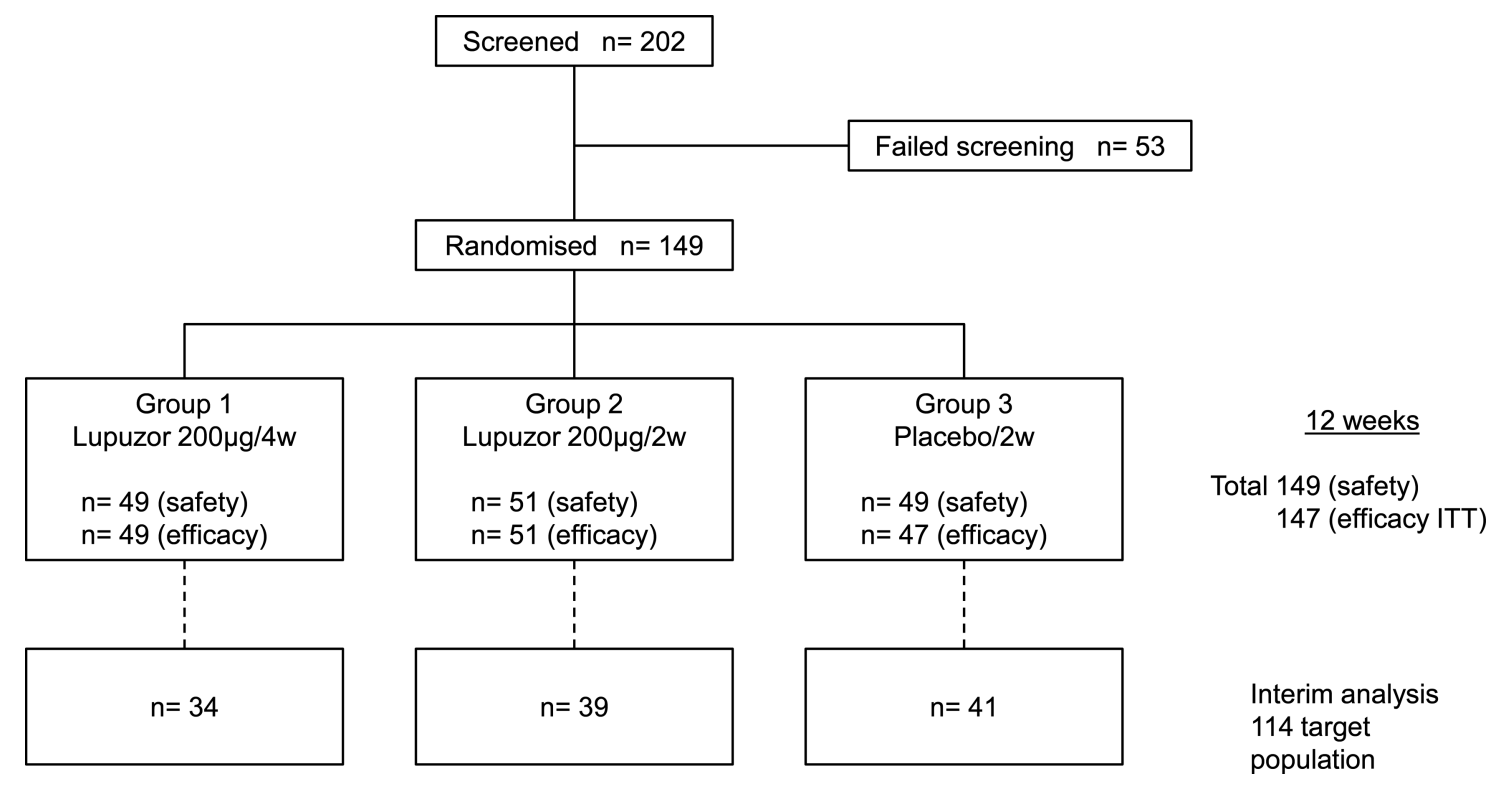

Figure 1 Flow chart to the patients who participated in the clinical trial. ITT, intention-to-treat. 
Table 1 Demographics, baseline characteristics and concomitant drugs

\begin{tabular}{|c|c|c|c|}
\hline & \multicolumn{2}{|l|}{ Lupuzor } & \multirow[b]{2}{*}{$\begin{array}{l}\text { Group } 3 \text { (placebo) } \\
(n=49)\end{array}$} \\
\hline & $\begin{array}{l}\text { Group } 1(200 \mu \mathrm{g} \text { every } 4 \text { weeks }) \\
(n=49)\end{array}$ & $\begin{array}{l}\text { Group } 2 \text { (200 } \mu \text { g every } 2 \text { weeks) } \\
(n=51)\end{array}$ & \\
\hline Age (years), mean (SD) & $39.2(11.0)$ & $38.2(12.6)$ & $35.3(12.1)$ \\
\hline Women, $\mathrm{n}(\%)$ & $47(96)$ & $50(98)$ & $47(96)$ \\
\hline Disease duration (years), mean (SD) & $7.8(7.9)$ & $8.0(7.5)$ & $7.2(7.3)$ \\
\hline \multicolumn{4}{|c|}{ History of disease manifestations (ACR classification criteria), n (\%) } \\
\hline Malar rash & $38(78)$ & $42(82)$ & $32(65)$ \\
\hline Discoid rash & $7(14)$ & $6(12)$ & $6(12)$ \\
\hline Photosensitivity & $38(78)$ & $37(73)$ & $38(78)$ \\
\hline Oral ulcers & $26(53)$ & $30(59)$ & $27(55)$ \\
\hline Arthritis & 47 (96) & 49 (96) & 47 (96) \\
\hline Serositis & $11(22)$ & $6(12)$ & $13(27)$ \\
\hline Renal disorder & $9(18)$ & $12(24)$ & $9(18)$ \\
\hline Neurological disorder & $2(4)$ & $3(6)$ & $4(8)$ \\
\hline Hematological disorder & $21(43)$ & $22(43)$ & $22(45)$ \\
\hline Immunological disorder & $38(78)$ & $43(84)$ & $42(86)$ \\
\hline Antinuclear antibodies, with titre $\geq 1: 160, n(\%)$ & $49(100)$ & $51(100)$ & $48(98)$ \\
\hline Antibodies to dsDNA (Farr assay), mean IU/ml & 133 & 120 & 75 \\
\hline SLEDAI-2K score, mean (SD) & $10.7(2.5)$ & $11.1(3.2)$ & $10.9(3.3)$ \\
\hline Patients with clinical SLEDAI-2K score $\geq 6, n(\%)$ & $42(86)$ & $48(94)$ & $46(94)$ \\
\hline Physician's global assessment, mean (SD) & $1.2(0.5)$ & $1.3(0.5)$ & $1.2(0.6)$ \\
\hline \multicolumn{4}{|l|}{ Concomitant drugs, n (\%) } \\
\hline Corticosteroids & $43(88)$ & $43(84)$ & $35(71)$ \\
\hline Antimalarial drugs & $30(61)$ & $34(67)$ & $43(88)$ \\
\hline Corticosteroids alone & 7 (14) & 7 (14) & $3(6)$ \\
\hline Corticosteroids and azathioprine & $12(25)$ & $12(24)$ & $8(16)$ \\
\hline Corticosteroids and antimalarial drugs & $27(55)$ & $26(51)$ & $31(63)$ \\
\hline Corticosteroids and methotrexate & $2(4)$ & $2(4)$ & $1(2)$ \\
\hline Antimalarial drugs alone & $3(6)$ & $8(16)$ & $12(25)$ \\
\hline Azathioprine alone & $1(2)$ & $2(4)$ & $3(6)$ \\
\hline Methotrexate alone & $1(2)$ & $2(4)$ & $0(0.0)$ \\
\hline
\end{tabular}

ACR, American College of Rheumatology; dsDNA, double-stranded DNA; SLEDAI-2K, Systemic Lupus Erythematosus Disease Activity Index 2000.

treatment groups (table 5). The most common AE was injectionsite erythema, which was seen in four injections in three patients in group 1, seven injections in five patients in group 2 and one injection in one patient in group 3. All local injection site reactions were mild and resolved rapidly.

A total of seven patients experienced serious AEs (table 5), including pneumonia (one patient in group 1 and two patients in group 3), herpes viral pneumonia (one patient in group 2), soft-tissue infection (one patient in group 1), diverticulitis (one

Table 2 Clinical response (SLEDAI) to treatment at weeks 12 and 24: interim analysis in the target population

\begin{tabular}{|c|c|c|c|}
\hline & \multicolumn{2}{|l|}{ Lupuzor } & \multirow[b]{2}{*}{$\begin{array}{l}\text { Group } 3 \\
\text { (placebo) }\end{array}$} \\
\hline & $\begin{array}{l}\text { Group } 1(200 \mu \mathrm{g} \\
\text { every } 4 \text { weeks) }\end{array}$ & $\begin{array}{l}\text { Group } 2(200 \mu \mathrm{g} \\
\text { every } 2 \text { weeks) }\end{array}$ & \\
\hline Week 12 & $n=34$ & $n=39$ & $n=41$ \\
\hline \multirow[t]{2}{*}{ Responders, n (\%) } & $23(67.6)$ & $20(51.3)$ & $17(41.5)$ \\
\hline & $p<0.025$ & $p=0.19$ & - \\
\hline Week 24 & $n=19$ & $n=21$ & $n=24$ \\
\hline \multirow[t]{2}{*}{ Responders, n (\%) } & $16(84.2)$ & $14(66.7)$ & $11(45.8)$ \\
\hline & $p<0.025$ & $p=0.15$ & - \\
\hline
\end{tabular}

patient in group 3) and gastritis (one patient in group 1). The patient in group 1 with pneumonia was the only one to die during the study. In the investigator's opinion, the pneumonia was not related to treatment with the study drug, although the concomitant administration of azathioprine and prednisone was considered to have contributed to the development of pneumonia. No clinically significant changes in haematology, chemistry, urine analysis, vital signs results or electrocardiography findings were reported during the course of the study.

Table 3 Clinical response (SRI) to treatment at weeks 12 and 24: overall ITT analysis

\begin{tabular}{|c|c|c|c|}
\hline & \multicolumn{2}{|l|}{ Lupuzor } & \multirow[b]{2}{*}{$\begin{array}{l}\text { Group } 3 \\
\text { (placebo) }\end{array}$} \\
\hline & $\begin{array}{l}\text { Group } 1(200 \mu \mathrm{g} \\
\text { every } 4 \text { weeks) }\end{array}$ & $\begin{array}{l}\text { Group } 2(200 \mu \mathrm{g} \\
\text { every } 2 \text { weeks) }\end{array}$ & \\
\hline Week 12 & $n=49$ & $\mathrm{n}=51$ & $\mathrm{n}=47$ \\
\hline \multirow[t]{2}{*}{ Responders, n (\%) } & $26(53.1)$ & $23(45.1)$ & $17(36.2)$ \\
\hline & $p=0.048$ & $p=0.18$ & - \\
\hline Week 24 & $n=49$ & $\mathrm{n}=51$ & $n=49$ \\
\hline \multirow[t]{2}{*}{ Responders, n (\%) } & $29(59.2)$ & $30(58.8)$ & $26(53.1)$ \\
\hline & $\mathrm{p}=0.27$ & $\mathrm{p}=0.28$ & - \\
\hline
\end{tabular}

$\mathrm{p}$ Values compare Lupuzor with placebo. Drop-outs are considered as non-responders. ITT, intention-to-treat; SRI, SLE Responder Index. 
Table 4 Clinical response (SRI) to treatment at weeks 12 and 24: ITT target population* analysis

\begin{tabular}{|c|c|c|c|}
\hline & \multicolumn{2}{|l|}{ Lupuzor } & \multirow[b]{2}{*}{$\begin{array}{l}\text { Group } 3 \\
\text { (placebo) }\end{array}$} \\
\hline & $\begin{array}{l}\text { Group } 1(200 \mu \mathrm{g} \\
\text { every } 4 \text { weeks) }\end{array}$ & $\begin{array}{l}\text { Group } 2(200 \mu \mathrm{g} \\
\text { every } 2 \text { weeks) }\end{array}$ & \\
\hline Week 12 & $n=42$ & $n=48$ & $n=44$ \\
\hline \multirow[t]{2}{*}{ Responders, n (\%) } & $26(61.9)$ & $23(48.0)$ & 17 (38.6) \\
\hline & $p=0.016$ & $p=0.18$ & - \\
\hline Week 24 & $n=42$ & $n=48$ & $n=46$ \\
\hline \multirow[t]{2}{*}{ Responders, n (\%) } & $29(69.1)$ & $30(62.5)$ & $26(56.5)$ \\
\hline & $p=0.11$ & $p=0.28$ & - \\
\hline \multicolumn{4}{|c|}{$\begin{array}{l}{ }^{*} \text { Corresponds to all ITT patients having a clinical SLEDAI } \geq 6 \text { at week } 0 \text {. } \\
\text { p Values compare Lupuzor with placebo. } \\
\text { ITT, intention-to-treat; SLEDAI, Systemic Lupus Erythematosus Disease Activity Index; } \\
\text { SRI, SLE Responder Index. }\end{array}$} \\
\hline
\end{tabular}

\section{DISCUSSION}

The results of this study show that administration of $200 \mu \mathrm{g}$ Lupuzor via subcutaneous injection every 4 weeks significantly reduced disease activity in patients with SLE who were receiving SOC. In a post hoc analysis, we evaluated the subgroup of patients considered as the target population with a clinical SLEDAI-2K score $\geq 6$ at baseline, which constituted about $90 \%$ of the overall study population. In this target population the percentage of patients receiving Lupuzor every 4 weeks who achieved an SRI response during the treatment period was statistically higher than that of the placebo group. The difference between the group receiving Lupuzor every 2 weeks and the placebo group did not reach statistical significance.

During the course of this study an interim analysis was performed post hoc for licensing purposes, and these results had to be disclosed according to the London Stock Exchange rules. This had an impact on the final ITT week 24 results for both overall and target populations as can be seen when the interim week 24 SLEDAI results (table 2) recorded before the disclosure in the target population and those of the ITT target population are compared. The responder rate in group 1 decreased from $84 \%$ (interim) to $69 \%$ (final), but the absolute number of

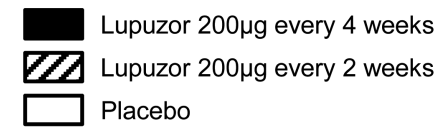

\section{Clinical SLEIDAI-2K score $\geq 6$}

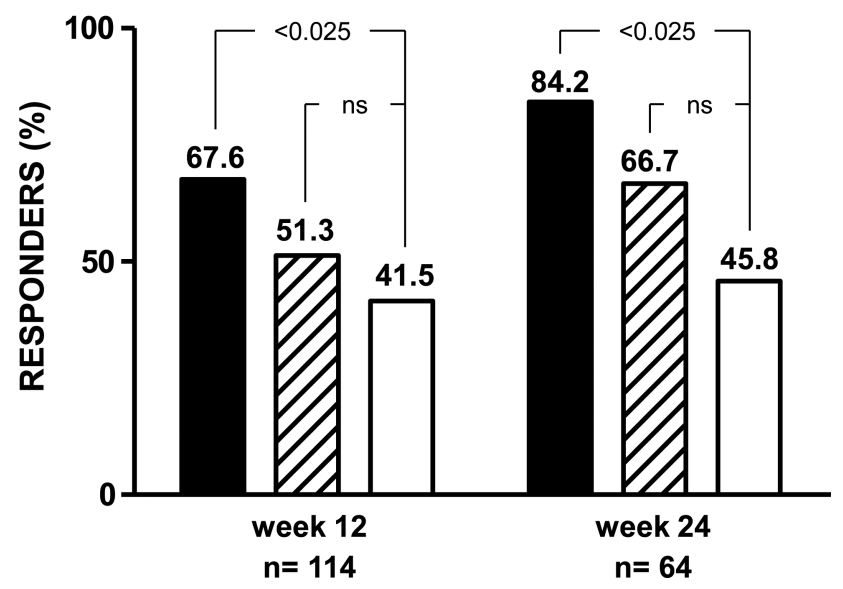

Figure 2 Percentage of patients achieving a clinical response according to SLEDAI score at weeks 12 and 24 (interim analysis). SLEDAI-2K, Systemic Lupus Erythematosus Disease Activity Index 2000.
Table 5 Summary of adverse events through week 24

\begin{tabular}{|c|c|c|c|}
\hline & \multicolumn{2}{|l|}{ Lupuzor } & \multirow[b]{2}{*}{$\begin{array}{l}\text { Group } 3 \\
\text { (placebo) }\end{array}$} \\
\hline & $\begin{array}{l}\text { Group } 1(200 \mu \mathrm{g} \\
\text { every } 4 \text { weeks) }\end{array}$ & $\begin{array}{l}\text { Group } 2(200 \mu \mathrm{g} \\
\text { every } 2 \text { weeks) }\end{array}$ & \\
\hline Patients treated, $\mathrm{n}$ & 49 & 51 & 49 \\
\hline Patients with $\geq 1 \mathrm{AE}, \mathrm{n}(\%)$ & $20(40.8)$ & $21(40.4)$ & $24(49.0)$ \\
\hline \multicolumn{4}{|c|}{ AEs that occurred in $\geq 5 \%$ of patients in any treatment group } \\
\hline Drop-outs owing to AEs & $1(2.0)$ & $0(0.0)$ & $4(8.2)$ \\
\hline $\begin{array}{l}\text { Injection-site erythema, } \\
\mathrm{n}(\%)\end{array}$ & $3(6.1)$ & $5(9.6)$ & $1(2.0)$ \\
\hline $\begin{array}{l}\text { Urinary tract infection, } \\
\mathrm{n}(\%)\end{array}$ & $2(4.1)$ & $2(3.8)$ & $5(10.2)$ \\
\hline Headache, n (\%) & $2(4.1)$ & $3(5.8)$ & $0(0.0)$ \\
\hline Nasopharyngitis, n (\%) & $1(2.0)$ & $4(7.7)$ & $0(0.0)$ \\
\hline Bronchitis, n (\%) & $3(6.1)$ & $1(1.9)$ & $0(0.0)$ \\
\hline Diarrhoea, $\mathrm{n}(\%)$ & $2(4.1)$ & $0(0.0)$ & $3(6.1)$ \\
\hline \multirow[t]{2}{*}{ Pharyngitis, n (\%) } & $1(2.0)$ & $0(0.0)$ & $3(6.1)$ \\
\hline & $3(6.1)$ & $1(1.9)$ & $3(6.1)$ \\
\hline \multicolumn{4}{|c|}{ Patients with $\geq 1$ serious $A E, n(\%)$} \\
\hline Pneumonia, n (\%) & $1(2.0)$ & $0(0.0)$ & $2(4.1)$ \\
\hline $\begin{array}{l}\text { Viral pneumonia (herpes), } \\
\mathrm{n}(\%)\end{array}$ & $0(0.0)$ & $1(1.9)$ & $0(0.0)$ \\
\hline $\begin{array}{l}\text { Soft-tissue infection, } \\
\mathrm{n}(\%)\end{array}$ & $1(2.0)$ & $0(0.0)$ & $0(0.0)$ \\
\hline Diverticulitis, n (\%) & $0(0.0)$ & $0(0.0)$ & $1(2.0)$ \\
\hline Gastritis, n (\%) & $1(2.0)$ & $0(0.0)$ & $0(0.0)$ \\
\hline Deaths, $\mathrm{n}(\%)^{*}$ & $1(2.0)$ & $0(0.0)$ & $0(0.0)$ \\
\hline
\end{tabular}

responders increased, whereas in the placebo group the responder rate increased from $45.8 \%$ to $56.5 \%$. In group 2 , the changes were limited. The SRI responses in the placebo group were particularly increased and the differences between the Lupuzor and placebo group were no longer statistically significant. It has to be mentioned that in groups 1 and 2 of the interim analysis (the active groups), the 12-week period provided $88 \%$ and $83 \%$ of the total SLEDAI responders versus $62 \%$ in the placebo group, indicating that the disclosure effect was huge. Therefore the week 24 data of the ITT group cannot be properly analysed from a clinical point of view. We wonder if the data recorded before the disclosure (table 2) are not the ones which correctly reflect the efficacy of Lupuzor.

Another point to discuss is the role of the inclusion criterianamely, the use of clinical SLEDAI compared with SLEDAI. Comparing the number of responders in the target population and those of the overall population it appears that there is no change. Exactly the same number of responders was recorded in the three groups in the overall population and the target population. This indicates that the commonly used inclusion criterion (SLEDAI score $\geq 6$ ) creates a bias in the evaluation of the study results in falsely reducing the response rate and therefore statistical analysis. In our study, changes in component 20 (complement) and/or 21 (anti-DNA antibodies) inducing a change in the SLEDAI score occurred only once in week 12 and 24 assessments but had no effect on the absolute number of responders. The anti-DNA antibody levels are either below four and remain below four (threshold value of DNA binding in the SLEDAI score when measures are based on the Farr assay) or are very high. In one published study, ${ }^{23}$ high anti-DNA antibody levels were requested as an inclusion criterion. In a previous study ${ }^{17}$ we demonstrated that anti-DNA antibody levels decreased by 
more than 20\% during treatment but never reached the threshold level. This was also the case in this study. In summary, if the end point of a clinical study in SLE is a reduction of the SLEDAI score of at least four points only clinical parameters can reasonably be involved. One has therefore to give enough 'room' in the inclusion criteria to allow this modification of four points in the clinical parameters. The use of a clinical SLEDAI inclusion criterion is therefore justified.

Lupuzor was generally well tolerated. The most common AE was injection-site erythema, which was generally mild. No unexpected serious AEs were reported. One patient who received Lupuzor died owing to pneumonia during the treatment period of the study. This patient had been previously treated with immunosuppressant agents and the investigator did not attribute this event to the study drug. Two patients in the placebo group also had pneumonia during the study. Thus, while there did not appear to be an increased incidence of serious infections with Lupuzor in this short study, longer-term studies are needed to further characterise the overall tolerability profile of Lupuzor.

Several limitations must be considered when interpreting the results of this study. First, the study was stopped before the planned enrolment was complete. However, the results reached statistical significance, demonstrating that Lupuzor was better than placebo. Second, the treatment period was only 12 weeks. However, the response of patients in the Lupuzor groups did not weaken during the subsequent 12 -week follow-up period but did not increase strongly. A longer treatment period appears necessary to increase the number of responders.

The peptide P140/Lupuzor is a promiscuous MHC class II binder that is recognised in this context by the $\mathrm{T}$ cell receptor of CD4 $\mathrm{T}$ cells from lupus patients and mice. ${ }^{11}{ }^{13} \mathrm{In}$ this molecular pathway it might act as an altered peptide ligand of the $\mathrm{T}$ cell receptor leading to a change of autoreactive $\mathrm{T}$ cell phenotype and a deviation of cytokines that are secreted. ${ }^{13}$ On the other hand, we showed in MRL/lpr mice that via its interaction with the HSC70 chaperone, P140 peptide might also operate by altering the autophagic flux, thus reducing the stability of MHC class II dimer in antigen-presenting cells and the presentation of self-antigens to autoreactive $\mathrm{T}$ cells. ${ }^{16}$ This mechanism of action of P140 peptide that targets autoreactive $\mathrm{T}$ cells is thus totally distinct from the one of $\mathrm{B}$ cell-depleting anti-BLyS monoclonal antibody belimumab, which was recently approved for the treatment of SLE. In phase III clinical trials, significantly higher SRI rates were noted with belimumab than with placebo at week 52. ${ }^{23} 24$ An activity index (SELENA-SLEDAI) $\geq 10$, low complement, anti-dsDNA antibody positivity and corticosteroid use were identified as baseline factors associated with an increased benefit of belimumab. ${ }^{25}$ From a methodological point of view the use of a target population with a clinical SLEDAI score $\geq 6$ at inclusion is justified for the phase III clinical programme.

In conclusion, the results of this study showed that Lupuzor provided statistically significant and clinically meaningful improvement of disease activity in a subpopulation of lupus patients with a SLEDAI-2K score $\geq 6$ with a more pronounced effect in a population with a clinical SLEDAI score $\geq 6$.

Acknowledgements We thank the patients, investigators and study personnel who made the trial possible. Enrico Chavez of Genexion SA conducted the statistical analysis. We thank Jean-Paul Briand and Nicolas Schall for assistance in the preparation of this report.

Funding This study was sponsored by ImmuPharma France, an affiliate of ImmuPharma plc, as part of a full clinical development programme.

Competing interests None.

Patient consent Obtained.
Ethics approval This study was proved by appropriate institutional review boards/ ethics committees.

Provenance and peer review Not commissioned; externally peer reviewed.

Open Access This is an Open Access article distributed in accordance with the Creative Commons Attribution Non Commercial (CC BY-NC 3.0) license, which permits others to distribute, remix, adapt, build upon this work non-commercially, and license their derivative works on different terms, provided the original work is properly cited and the use is non-commercial. See: http://creativecommons.org/ licenses/by-nc/3.0/

\section{REFERENCES}

1 Rahman A, Isenberg DA, Systemic lupus erythematosus. N Engl J Med 2008;358:929-39.

2 Tsokos GC. Systemic lupus erythematosus. N Engl J Med 2011;365:2110-21.

3 Arbuckle MR, McClain MT, Rubertone MV, et al. Development of autoantibodies before the clinical onset of systemic lupus erythematosus. N Engl J Med 2003;349:1526-33.

4 Gateva V, Sandling JK, Hom G, et al. A large-scale replication study identifies TNIP1, PRDM1, JAZF1, UHRF1BP1 and IL10 as risk loci for systemic lupus erythematosus. Nat Genet 2009;41:1228-33.

5 Taylor KE, Chung SA, Graham RR, et al. Risk alleles for systemic lupus erythematosus in a large case-control collection and associations with clinical subphenotypes. PLoS Genet 2011;7:e1001311.

6 Merrill JT, Erkan D, Buyon JP. Challenge in bringing the bench to bedside in drug development for SLE. Nature Rev Drug Discov 2004;3:1036-46.

7 Steinman L, Merrill JT, McInnes IB, et al. Optimization of current and future therapy for autoimmune diseases. Nat Med 2012;18:59-65.

8 Lee SJ, Silverman E, Bargman JM. The role of antimalarial agents in the treatment of SLE and lupus nephritis. Nat Rev Nephrol 2011;7:718-29.

9 Larche M, Wraith DC. Peptide-based therapeutic vaccines for allergic and autoimmune diseases. Nat Med 2005;11:S69-76.

10 Raz I, Elias D, Avron A, et al. Beta-cell function in new-onset type 1 diabetes and immunomodulation with a heat-shock protein peptide (DiaPep277): a randomised, double-blind, phase II trial. Lancet 2001;358:1749-53.

11 Monneaux F, Lozano JM, Patarroyo ME, et al. T cell recognition and therapeutic effect of a phosphorylated synthetic peptide of the 70K snRNP protein administered in MR/lpr mice. Eur J Immunol 2003;33:287-96.

12 Monneaux F, Parietti V, Briand JP, et al. Intramolecular T cell spreading in unprimed $\mathrm{MRL} /$ /pr mice: importance of the U1-70K protein sequence 131-151. Arthritis Rheum 2004;50:3232-8.

13 Monneaux F, Hoebeke J, Sordet C, et al. Selective modulation of CD4+ T cells from lupus patients by a promiscuous, protective peptide analogue. J Immunol 2005; 175:5839-47.

14 Monneaux F, Parietti V, Briand JP, et al. Importance of spliceosomal RNP1 motif for intermolecular T-B cell spreading and tolerance restoration in lupus. Arthritis Res Ther 2007;9:R111.

15 Page N, Schall N, Strub JM, et al. The spliceosomal phosphopeptide P140 controls the lupus disease by interacting with the HSC70 protein and via a mechanism mediated by $\gamma \delta$ T cells. PloS ONE 2009;4:e5273.

16 Page N, Gros F, Schall N, et al. HSC70 blockade by the therapeutic peptide P140 affects autophagic processes and endogenous MHCII presentation in murine lupus. Ann Rheum Dis 2011;70:837-43.

17 Muller S, Monneaux F, Schall N, et al. Spliceosomal peptide P140 for immunotherapy of systemic lupus erythematosus: results of an early phase II clinical trial. Arthritis Rheum 2008:58:3873-3.

18 Tan EM, Cohen AS, Fries JF, et al. The 1982 revised criteria for the classification of systemic lupus erythematosus. Arthritis Rheum 1982;25:1271-7.

19 Hochberg MC. Updating the American College of Rheumatology revised criteria for the classification of systemic lupus erythematosus. Arthritis Rheum 1997;40:1725.

20 Isenberg DA, Rahman A, Allen E, et al. BILAG 2004. Development and initial validation of an updated version of the British Isles Lupus Assessment Group's disease activity index for patients with systemic lupus erythematosus. Rheumatology (Oxford) 2005;44:902-6.

21 Yee CS, Farewell V, Isenberg DA, et al. The BILAG-2004 index is sensitive to change for assessment of SLE disease activity. Rheumatology (Oxford) 2009;48:691-5.

22 Petri M. Postmenopausal estrogen replacement therapy and risk of developing systemic lupus erythematosus or discoid lupus. J Rheumatol 1999;26:752.

23 Furie R, Petri M, Zamani O, et al. BLISS-76 Study Group. A phase III, randomized, placebo-controlled study of belimumab, a monoclonal antibody that inhibits $B$ lymphocyte stimulator, in patients with systemic lupus erythematosus. Arthritis Rheum 2011;63:3918-30.

24 Navarra SV, Guzmán RM, Gallacher AE, et al. BLISS-52 Study Group. Efficacy and safety of belimumab in patients with active systemic lupus erythematosus: a randomised, placebo-controlled, phase 3 trial. Lancet 2011;377:721-31.

25 van Vollenhoven RF, Petri MA, Cervera $R$, et al. Belimumab in the treatment of systemic lupus erythematosus: high disease activity predictors of response. Ann Rheum Dis 2012;71:1343-9. 